\title{
Hygroscopic Behavior and Thermodynamic Properties of Ziziphus joazeiro Mart. Kernel Flour
}

\author{
Hanndson Araujo Silva (Corresponding Author), Josivanda Palmeira Gomes, Alexandre José \\ de Melo Queiroz
}

Food Engineering Departament, Federal University of Campina Grande, Brazil

Received: Dec. 4, 2019

doi:10.5296/jas.v8i3.15976
Accepted: Jan. 15, $2020 \quad$ Published: Jan. 16, 2020

URL: https://doi.org/10.5296/jas.v8i3.15976

\begin{abstract}
The hygroscopic and thermal behavior of kernel flour from Ziziphus joazeiro fruits were investigated. Adsorption isotherms were obtained at temperatures of 293, 303 and $313 \mathrm{~K}$ and adjusted to GAB, Oswin and Peleg models. The best fit of the experimental data was obtained with the GAB model with $\mathrm{R}^{2}$ values $>0.994$ and mean percentage deviation $\mathrm{P}<10 \%$. The isotherms obtained were sigmoidal type II. Isosteric heat and other thermodynamic properties were calculated as a function of moisture content. Adsorption isosteric heat decreased exponentially with increasing moisture content and differential entropy increased with moisture content, while differential enthalpy decreased. The theory of compensation confirmed that these properties are dependent on moisture content. The isotherms presented a spontaneous and enthalpy process.
\end{abstract}

Keywords: Hygroscopic behavior, thermodynamic properties, isosteric heat, Ziziphus joazeiro

\section{Introduction}

(Ziziphus joazeiro Mart), popularly known as juá, is a tropical fruit from the Rhamnaceae Ziziphus plant that is an endemic caatinga species mostly found on the northeastern Brazil (Brito et al., 2015).

Beyond the use for food, the local population uses the leaves, bark and roots for many other purposes comprising the production of traditional remedies for the treatment of several diseases (Brito et al., 2015). However, despite being a species widely used by the northeastern semiarid population, the exploitation of juazeiro is limited to extractivism (Silva et al., 2018).

For effective use and increasing the added value of seeds and grains, long term storage is essential (Lisboa et al., 2019). The moisture removal process is used to improve this shelf life 
because the presence of moisture in kernel stimulates the development of microorganisms, causing irreversible damage and decreasing product quality (Avhad \& Marchetti, 2016).

Knowledge of water sorption behavior becomes a necessary study to properly design drying equipment and processes. Using more accurate product drying procedures can prevent undesirable effects that may occur on the quality of the raw material. Sorption isotherms provide information on equilibrium moisture content (Xeq) and water activity $\left(\mathrm{a}_{\mathrm{w}}\right)$, simulating different relative humidity in equilibrium with the product (Polachini et al., 2016).

Liquid isosteric heat, enthalpy and differential entropy, and Gibbs free energy can be calculated from the sorption isotherms. These properties provide essential information about the sorption mechanism and drying process in terms of energy requirements (Aksil et al., 2019).

To date there is no research on the behavior of isotherms and thermodynamic properties of juá kernel reported in the literature. This fact justifies the study of their hygroscopic behavior aiming to provide information to prolong the shelf life of this unexploited product in the caatinga biome. Moreover, additional technological information can increase the uses and exploration of juá fruit. Therefore, the objective of this work was to describe the adsorption isotherms of juá kernels for different temperature conditions by evaluating the hygroscopic behavior and thermodynamic parameters by mathematical modeling, verifying the best fit to the experimental data.

\section{Material and Methods}

\subsection{Raw Material}

The fruits of juá (Ziziphus joazeiro Mart.) were collected in great state of maturity in Ziziphus joazeiro trees located at the Campina Grande campus of the Federal University of Campina Grande (UFCG)-PB.

\subsection{Fruit Processing, Kernel Extraction and Flour Production}

The fruits were previously washed in running water to remove impurities, then sanitized with chlorinated water for $15 \mathrm{~min}$ and rinsed with running water. Afterwards, the fruits were manually pulped, and from the residue generated by this processing the seeds were obtained. After these processes the seeds were broken to obtain the kernel and later stored in polyethylene packaging for use in the analyzes. Then the kernel were convectively dried at $343 \mathrm{~K}$ and afterwards were ground using a knife mill.

\subsection{Kernel Characterization}

Freshly extracted and kernel flour were characterized for moisture content following the (AOAC method. 934.06, 2000). Lipid content was determined using chloroform and methanol (Bligh \& Dyer method, 1959). Protein content was quantified by the Kjeldahl method with a conversion factor of 6.25 (AOAC method. 979.09, 2000). The ash content was determined by incinerating the samples in muffle furnace at $550{ }^{\circ} \mathrm{C}$ (AOAC method 923.03, 2000). Carbohydrate content was quantified by calculating the difference to $100 \%$. 


\subsection{Adsorption Isotherms}

Adsorption isotherms were determined by applying the static-indirect method at temperatures of 293, 303 and $313 \mathrm{~K}$ using the Decal Devices Aqualab Model 3TE water activity determinant (Crapiste \& Rotstein, 1982). To set up a moisture-saturated environment, an airtight glass container filled with approximately $200 \mathrm{~mL}$ of distilled water was used. The vessel was placed in a constant temperature chamber and allowed to equilibrate moisture prior to each adsorption experiment. Approximately $1.5 \mathrm{~g}$ of flour was placed in a capsule and introduced into the container for the adsorption of water from the moisture saturated environment. At first, the sample was held for 5, 10, 20 and 30 min to adsorb moisture, and then intervals increased from 60 to $120 \mathrm{~min}$ for the last measurements. The methodology was repeated at 293, 303 and $313 \mathrm{~K}$. After these time intervals, the sample was removed from the container, transferred to the water activity $\left(\mathrm{a}_{\mathrm{w}}\right)$ meter for measurement and then weighed on the scale. Then the sample was returned to the container to continue adsorbing moisture and the procedure was repeated until an $\mathrm{a}_{\mathrm{w}}$ value of about 0.9 was obtained.

\subsection{Mathematical Modeling of Adsorption Isotherms}

For the mathematical adjustment of the flour adsorption experimental data the Peleg, GAB and Oswin models were used (Table 1). The model parameters were determined by nonlinear regression using the Levenberg-Marquardt method in Statistica 12.0.

Table 1. Adjustment models of moisture adsorption isotherms.

\begin{tabular}{l|l}
\hline Model & \multicolumn{1}{|c}{ Equation } \\
\hline PELEG & $X e q=k_{1} a_{w}^{n 1}+k_{2} a_{w}^{n 2}$ \\
\hline GAB & $\mathrm{C}=\mathrm{C} 0 \frac{x_{m} c k a_{w}}{\left(1-k a_{w}\right)\left(1-C k a_{w}\right)}\left(\frac{\Delta H m}{R T}\right)$ \\
& $\mathrm{k}=\mathrm{k} 0 \exp \left(\frac{\Delta H t c}{R T}\right)$ \\
\hline OSWIN & $X X_{m}=X_{0} \exp \left(\frac{\Delta H_{X}}{R T}\right)$ \\
\hline & $X e q=a\left(\frac{a_{w}}{\left(1-a_{w}\right)}\right)$ \\
\hline
\end{tabular}




\section{Macrothink}

Journal of Agricultural Studies

ISSN 2166-0379

2020, Vol. 8, No. 3

Xeq - Equilibrium humidity (\% dry basis); $\mathrm{a}_{\mathrm{w}}$ - Water activity; Xm - Moisture in molecular monolayer; $\mathrm{C}$ e $\mathrm{K}$ - Parameters that depend on the temperature and nature of the product; a e b-Model fit parameters; k1. k2. n1 e n2-Model Constants

Where $\mathrm{C}_{0}$ and $\mathrm{k}_{\mathrm{o}}$ are the pre-exponential factors; $\mathrm{T}$ is the absolute temperature; $\mathrm{R}$ is the universal gas constant. 8.3145 $\mathrm{J} \mathrm{mol}^{-1} \mathrm{~K}^{-1} ; \Delta \mathrm{Hm}\left(\mathrm{J} \mathrm{mol}^{-1}\right)$. or the water absorption heat, is equal to the difference between the monolayer sorption heat $(\mathrm{Hm})$ and the multilayer water sorption heat $(\mathrm{Hn}) . \Delta \mathrm{Htc}\left(\mathrm{J} \mathrm{mol}^{-1}\right)$ is the difference between the latent heat of pure water vaporization $(\mathrm{HG})$ and the sorption heat of multi-layer water $(\mathrm{Hn})$.

To determine the parameters of the GAB equation, two methods were used. Direct regression is the method where Equations (4) and (5) are added to Equation (1), so all six parameters are determined together. In the indirect method. we determine the three parameters of the GAB equation individually for each temperature and then use a linearization of both Arrhenius (4) and (5) equations to determine the remainder of the parameters.

The criteria used to determine the best fit of the models to the experimental data was: the coefficient of determination $\left(\mathrm{R}^{2}\right)$. the sum of the squares regression (SSE) and the absolute mean minimum percentage of error $(\mathrm{P})$. calculated by Eq. 10 .

$$
\begin{gathered}
R^{2}=\frac{S S E r}{S S E t} \\
\operatorname{SSEr}=\sum_{i=1}^{n}(\operatorname{Xeq}(\exp )-\operatorname{Xeq}(\text { teo }))^{2} \\
R M S E=\sqrt{\frac{S S E}{n-m}} \\
P=\frac{100}{n} \sum_{i=1}^{n}\left(\frac{x_{\text {eq }(\exp )}-X_{\text {eq }(t e o)}}{X_{\text {eq }(e x p)}}\right)
\end{gathered}
$$

Where,

$\mathrm{P}$ - mean percentage deviation. \%;

$\mathrm{X}_{\mathrm{eq}(\exp )}$ - experimental equilibrium humidity. \% d.b;

$\mathrm{X}_{\mathrm{eq}(\mathrm{teo})}$ - equilibrium humidity estimated by the model. \% d.b; e.

$\mathrm{n}$ - number of experimental data.

$\mathrm{m}-$ number of adjusted coefficients.

\subsection{Thermodynamic Properties}

The isosteric sorption heat $\left(\mathrm{Q}_{\mathrm{st}}\right)$ was calculated according to the Clausius-Clapeyron equation (Eq. 11). Application of this method requires the determination of adsorption isotherms at least 


\section{MIMacrothink}

three temperatures (Miltal \& Usborne, 1985).

$$
\partial \ln a w / \partial T=Q s t / \mathrm{RT}^{2}
$$

Where $\mathrm{R}$ is the gas constant $(\mathrm{R}=8.314 \mathrm{~J} / \mathrm{mol} / \mathrm{K})$. $\mathrm{T}$ is the absolute temperature $(\mathrm{K})$ and $\mathrm{Q}_{\mathrm{st}}$ is the net isosteric adsorption heat $\left(\mathrm{kJ} \mathrm{mol}^{-1}\right)$. Integrating Eq. 12, we have the following relation:

$$
\ln \text { aw }=\frac{\left(\frac{\text { (st }}{R}\right)}{T}+K
$$

To describe the relationship between equilibrium water content and Qst, the Reidel equation (Eq. 13) was used:

$$
\text { Qst }=\text { Cr e } \text { enXeq }^{- \text {rXe }}
$$

where $\mathrm{Cr}$ and $\mathrm{Br}$ are coefficients of the model.

The proposed calculation for thermodynamic properties was based on the Gibbs - Helmholtz energy calculated by Eq. 14:

$$
\Delta G=R T \ln a w
$$

Obtaining Gibbs free energy, differential entropy $(\Delta S)$ was calculated from Eq. 15, this property is associated with the forces of attraction or repulsion between water molecules and product components and is linked to the spatial arrangement of the absorber, of water (Aksil et al., 2019).

$$
\Delta \mathrm{S}=\frac{\Delta \mathrm{H}-\Delta \mathrm{G}}{\mathrm{T}}=(\mathrm{Q} \mathrm{st}-\Delta \mathrm{G}) / \mathrm{T}
$$

Correlating the values obtained from $\Delta \mathrm{H}$ versus $\Delta \mathrm{S}$ for adsorption data, it is expected that a linear trend confirms the compensation theory for adsorption using Eq. 16. In this relationship. $\mathrm{Tb}$ is the isokinetic temperature and represents the temperature at which all reactions series are processed at the same speed.

$$
\Delta \mathrm{H}=\mathrm{Tb}(\Delta \mathrm{S})+\Delta \mathrm{G}
$$

\section{Results and Discussion}

\subsection{Centesimal Composition of Fresh and Powdered Kernels}

The proximate composition of kernel was chemically determined before and after the drying process, allowing the evaluation of changes in flour composition. Considering the data presented in Table 2, the moisture content presented a high value in fresh kernel, however after the drying process there was a reduction of approximately $95 \%$ in the amount of water 


\section{Al Macrothink}

Journal of Agricultural Studies

ISSN 2166-0379 2020, Vol. 8, No. 3

on the flour. This fact corroborates the studies of (Campidelli et al., 2019; Lisboa et al., 2019) confirming the need for the drying process to remove water from the product, providing safe storage. The increase on all other constituents is due to water removal. Analysing the contents of juá flour it is noticeable the greater amount of proteins, then fat and finally the carbohydrates.

Table 2. Centesimal composition of fresh and dried Ziziphus joazeiro kernel

\begin{tabular}{lcc} 
Parameter & Kernel in natura & Kernel flour \\
\hline Moisture (\%) & $60.51 \pm 0.99$ & $3.30 \pm 0.00$ \\
Proteins (\%) & $23.62 \pm 0.42$ & $42.91 \pm 0.42$ \\
Fats (\%) & $7.64 \pm 0.25$ & $25.98 \pm 0.50$ \\
Ashes (\%) & $1.79 \pm 0.13$ & $4.35 \pm 0.02$ \\
Carbohydrates $(\%)$ & $6.43 \pm 0.05$ & $23.46 \pm 0.25$ \\
\hline
\end{tabular}

\subsection{Adsorption Isotherms}

Figure 1 shows the water adsorption isotherms of the kernel flour at temperatures of 293, 303 and $313 \mathrm{~K}$, with adjustments by the GAB model. The equilibrium water content (Xeq, \% b.s.) and water activity $\left(\mathrm{a}_{\mathrm{w}}\right)$ values were obtained in the range 2.070 to 33.08 and 0.1210 to 0.934 , respectively. As expected, isotherms presented an increase in equilibrium water content with the increase in water activity. Also, for the same water activity, an higher equilibrium water content is found when the temperature is increased. This tendency suggests a reduction in the total number of active water binding sites. Particulary, as the temperature increases, the water molecules become more excited, thus reducing intermolecular interactions and decreasing the attraction force with the product material (Saleh, Karim, Hensel \& Sturm, 2018; Santos et al., 2011). 


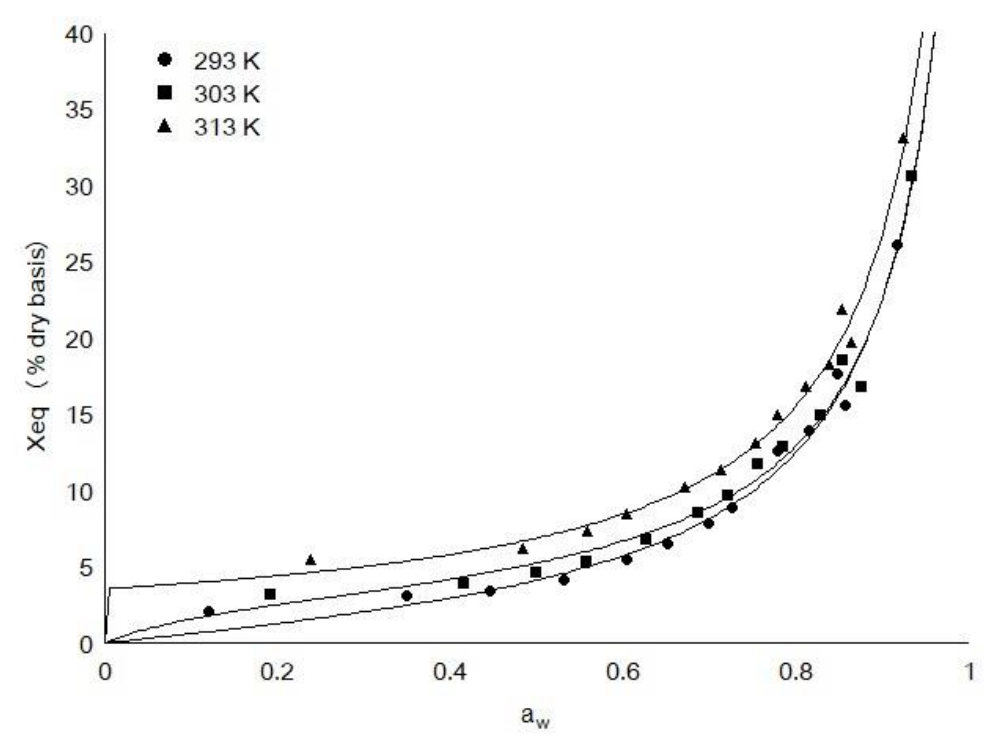

Figure 1. Water adsorption isotherms of juá kernel flour at 293, 303 and $313 \mathrm{~K}$ adjusted by the GAB model

From figure 1, all isotherm curves have a sigmoidal curve with an intermediate flat region thus reflecting the characteristics of type II isotherms. This type of isotherm can be classified into three regions: the first corresponds to the moisture of the monolayer strongly linked to the product matrix; the second is almost linear, corresponding to the water at the material multilayer; and the third region is related to the free water available for chemical reactions (Polachini et al., 2016; Torres \& Seijo, 2016). Analysing figure 1, the first region occupies most of the isotherm, evidenced by the small increase in equilibrium moisture until water activities of 0.6. Since our flour is majorly composed by proteins and polysaccharides, this result suggests water is highly bound to these hydrophilic macromolecules (Chisté et al., 2015).

\subsection{Mathematical Modeling of the Absorption Isotherms}

Water adsorption isotherms were determined for the juá kernel flour at temperatures of 293, 303 and $313 \mathrm{~K}$. Table 3 presents the coeficients of the GAB model, determined by the direct and indirect method, and the Oswin and Peleg models. All models showed good fit to experimental data with values $\mathrm{R}^{2}>0.98$ and $\mathrm{P}<10 \%$. The GAB model presented the best fits for temperatures of 303 and $313 \mathrm{~K}$ with $\mathrm{R}^{2}=0.99$ and $\mathrm{P}<6 \%$. The Peleg model presented the best adjustment for the temperature of $20^{\circ} \mathrm{C}$ with $\mathrm{R}^{2}=0.99$ and $\mathrm{P}<6 \%$. The GAB model determined by the indirect regression presented the best adjustments for the studied temperatures for the juá kernel flour. 
Table 3. Regressed parameters of the GAB, Peleg and Oswin models of the juá kernel flour adsorption isotherm, coefficients of determination $\left(\mathrm{R}^{2}\right)$ and mean percentage deviations $(\mathrm{P})$ at temperatures of 293,303 and $313 \mathrm{~K}$

\begin{tabular}{|c|c|c|c|c|c|c|c|c|c|c|}
\hline \multirow{2}{*}{ Direct regression of the GAB Model } & \multicolumn{5}{|c|}{ Coefficients } & \multirow[t]{2}{*}{$\mathrm{R}^{2}(\%)$} & \multirow[t]{2}{*}{ SSE } & \multirow[t]{2}{*}{ RMSE } & \multirow[t]{2}{*}{$\mathrm{P}(\%)$} & \multirow[t]{2}{*}{ Residual versus predicted } \\
\hline & $\mathrm{Xm}$ & $\mathrm{C}$ & $\mathrm{k}$ & $\Delta \mathrm{Hm}$ & $\Delta \mathrm{Htc}$ & & & & & \\
\hline & & & & -18497.4 & 2501.41 & & & & & \\
\hline $293 \mathrm{~K}$ & $3.45 \pm 0.004$ & $3.82 \pm 0.005$ & $0.95 \pm 0.001$ & & & 98.34 & 14.73 & 0.67 & 12.6 & Random \\
\hline $303 \mathrm{~K}$ & $4.44 \pm 0.002$ & $4.57 \pm 0.007$ & $0.92 \pm 0.002$ & & & 99.39 & 12.68 & 0.62 & 9.48 & Random \\
\hline $313 \mathrm{~K}$ & $5.62 \pm 0.008$ & $5.42 \pm 0.004$ & $0.90 \pm 0.008$ & & & 98.73 & 9.45 & 0.54 & 6.12 & Random \\
\hline \multirow{2}{*}{ Indirect regression of the GAB Model } & $\mathrm{Xm}$ & $\mathrm{C}$ & $\mathrm{k}$ & $\Delta \mathrm{Hm}$ & $\Delta \mathrm{Htc}$ & $\mathrm{R}^{2}(\%)$ & SSE & RMSE & $\mathrm{P}(\%)$ & Residual versus predicted \\
\hline & & & & -130172.3 & -409.382 & & & & & \\
\hline $293 \mathrm{~K}$ & $5.00 \pm 0.004$ & $1.48 \pm 0.002$ & $0.91 \pm 0.003$ & & & 99.51 & 21.96 & 0.82 & 10.8 & Random \\
\hline $303 \mathrm{~K}$ & $4.66 \pm 0.006$ & $7.40 \pm 0.003$ & $0.92 \pm 0.001$ & & & 99.29 & 38.46 & 1.08 & 10.6 & Random \\
\hline $313 \mathrm{~K}$ & $4.56 \pm 0.006$ & $45.60 \pm 0.008$ & $0.93 \pm 0.006$ & & & 99.55 & 10.96 & 0.58 & 5.6 & Random \\
\hline Other models & \multicolumn{4}{|c|}{ Coefficients } & $\mathrm{R}^{2}(\%)$ & SSE & RMSE & $\mathrm{P}(\%)$ & & Residual versus predicted \\
\hline Peleg & $\mathrm{k} 1$ & $\mathrm{n} 1$ & $\mathrm{k} 2$ & $\mathrm{n} 2$ & & & & & & \\
\hline $293 \mathrm{~K}$ & $35.3 \pm 0.015$ & $5.00 \pm 0.01$ & $5.35 \pm 0.20$ & $0.48 \pm 0.01$ & 98.73 & 9.45 & 0.54 & 12.6 & & Random \\
\hline $303 \mathrm{~K}$ & $33.7 \pm 0.50$ & $5.14 \pm 0.02$ & $4.33 \pm 0.01$ & $0.36 \pm 0.01$ & 98.97 & 7.62 & 0.49 & 5.73 & & Random \\
\hline $313 \mathrm{~K}$ & $35.20 \pm 0.01$ & $6.00 \pm 0.002$ & $9.30 \pm 0.30$ & $0.33 \pm 0.01$ & 99.62 & 2.37 & 0.26 & 3.4 & & Random \\
\hline Oswin & \multicolumn{2}{|c|}{$\mathrm{a}$} & \multicolumn{2}{|c|}{$\mathrm{b}$} & $\mathrm{R}^{2}$ & SSE & RMSE & $\mathrm{P}(\%)$ & & Residual versus predicted \\
\hline $293 \mathrm{~K}$ & \multicolumn{2}{|c|}{$5.80 \pm 0.001$} & \multicolumn{2}{|c|}{$0.70 \pm 0.01$} & 98.25 & 12.98 & 0.63 & 13.54 & & Random \\
\hline $303 \mathrm{~K}$ & \multicolumn{2}{|c|}{$6.76 \pm 0.002$} & \multicolumn{2}{|c|}{$0.57 \pm 0.008$} & 99.18 & 5.79 & 0.42 & 8.3 & & Random \\
\hline $313 \mathrm{~K}$ & \multicolumn{2}{|c|}{$8.30 \pm 0.01$} & \multicolumn{2}{|c|}{$0.54 \pm 0.02$} & 99.00 & 6.24 & 0.44 & 6.55 & & Biased \\
\hline
\end{tabular}

Molecular monolayer $\left(\mathrm{X}_{\mathrm{m}}\right)$ is a critical parameter as it represents the water content at which the rate of any associated reaction will be negligible due to the strong water binding to the product matrix (Yogendrarajah et al., 2015). Considering the best model, the values of Xm, decreased with increasing isotherm temperature, from $5.0 \%$ to $4.56 \%$. From a practical point of view this means that drying below this value tends to produce a high energy expenditure due to the strong water binding (Torres \& Seijo, 2016). The water activity values for each Xm value were $0.566,0.543$ and 0.275 for temperatures of 293,303 and $313 \mathrm{~K}$, respectively, and are considered optimal values for product stability during storage as pointed by (Aksil et al., 2019).

Parameter $\mathrm{C}$ is related to potential chemical differences between the monolayer and the upper layer (Santos et al., 2011). The values of this parameter ranged from 1.26 to 45.61 and followed an upward trend with temperature. This trend is probably due to the strong binding energy of water molecules in the monolayer, and may also be related to a higher rate of surface evaporation due to greater excitation of water molecules (Baptestini et al., 2017).

The constant $\mathrm{K}$ of the GAB model represents the capacity of multi-layer water adsorption (Abebe \& Ronda, 2015). K values of juá flours presented values ranging between 0.91 and 0.93. It is common to find higher $\mathrm{K}$ values in drier products. which confirms the trend reported by (Polachini et al., 2016), which observed increasing values of $\mathrm{K}$ as the temperature gets higher and, consequently, the equilibrium moisture content and the monolayer humidity 


\section{Macrothink}

Journal of Agricultural Studies

ISSN 2166-0379

2020, Vol. 8, No. 3

decrease. Higher $\mathrm{K}$ values indicate that the multilayer sorption heat is higher at higher temperatures, which means that the monolayer sorption heat tends to be higher than the multilayer (Santos et al., 2011).

Analyzing the parameters of $\mathrm{C}$ and $\mathrm{K}$ of the $\mathrm{GAB}$ model, the water adsorption isotherms for juá flour are Type II (sigmoid form), according to the classification of (Blahovec, 2004) because they presented $0<\mathrm{K} \leq 1$ and $\mathrm{C}>2$.

\subsection{Thermodynamic Properties}

Figure 2 presents the isosteric heat $\left(\mathrm{Q}_{\mathrm{st}}\right)$ as a function of equilibrium water content $\left(\mathrm{X}_{\mathrm{eq}}\right)$. It was observed that $\mathrm{Q}_{\text {st }}$ decreases with increasing equilibrium moisture ranging between 4336.3 and $194.8 \mathrm{k} \mathrm{J} / \mathrm{mol}$. This indicates that high Qst values are found at lower moisture contents. This behavior corroborates the results of (Aksil et al., 2019; Polachini et al., 2016; and Nascimento et al., 2019). The results indicate that there is a strong bond between the water molecules and the molecules present in the product monolayer, however, a rapid decrease in isosteric heat of adsorption occurs when the moisture content begins to increase due to the adsorption of water molecules in the multilayer. Also, according to (Freitas et al., 2016 and Nascimento et al., 2019) greater energy is required to remove water from dry products. Moreover, Reidel equation was used to fit the the experimental data by non-linear regression. The regression coefficients were $\mathrm{Cr}=10153.2 \mathrm{~J} / \mathrm{mol}$ and $\mathrm{Br}=0.295$ and the coefficient of determination was $\mathrm{R}^{2}=0.85$.



Figure 2. Isosteric heat (Qst) as a function of equilibrium moisture content (Xeq)

The relation between enthalpy $(\Delta \mathrm{H})$ and entropy $(\Delta \mathrm{S})$ is defined as the compensation theory, which is an important point to demonstrate the dependence of these thermodynamic parameters on equilibrium water content. A linear trend is observed in Figure 3, with $\mathrm{R}^{2}>$ 0.999, indicating simultaneous changes in enthalpy, entropy and Gibbs free energy. According to (Polachini et al., 2016), the enthalpy that is associated with Gibbs free energy tends to assume values close to zero when the equilibrium water content is increased, 


\section{Macrothink}

indicating that the process is spontaneous when there is multilayer adsorption of water molecules.

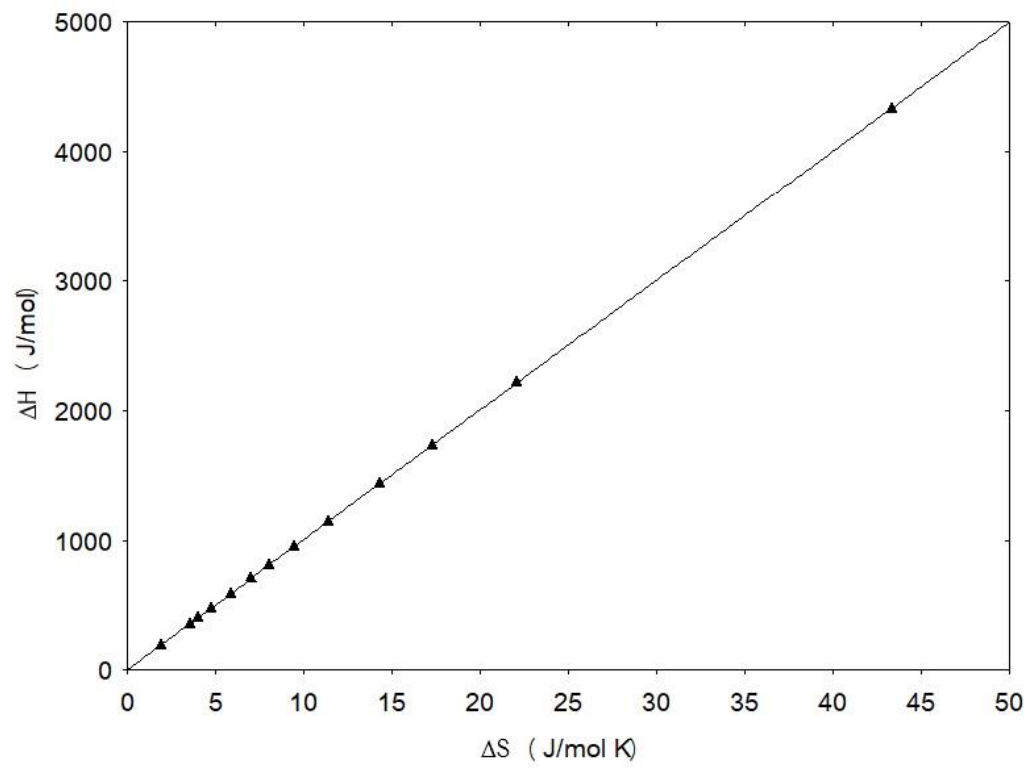

Figure 3. Enthalpy $(\Delta \mathrm{H})$-entropy $(\Delta \mathrm{S})$ ratio of adsorption processes for juá kernel flour

From the graph shown in Figure 4, a value of $373.15 \mathrm{~K}$ was obtained for the isokinetic temperature, which is defined as the temperature at which all reactions occur. The presence of higher $\mathrm{T}_{\mathrm{b}}$ values (above $300 \mathrm{~K}$ ) were characteristics observed and reported by (Polachini et al., 2016) for products with high sugar or starch content, such as potato, plum and apricot.

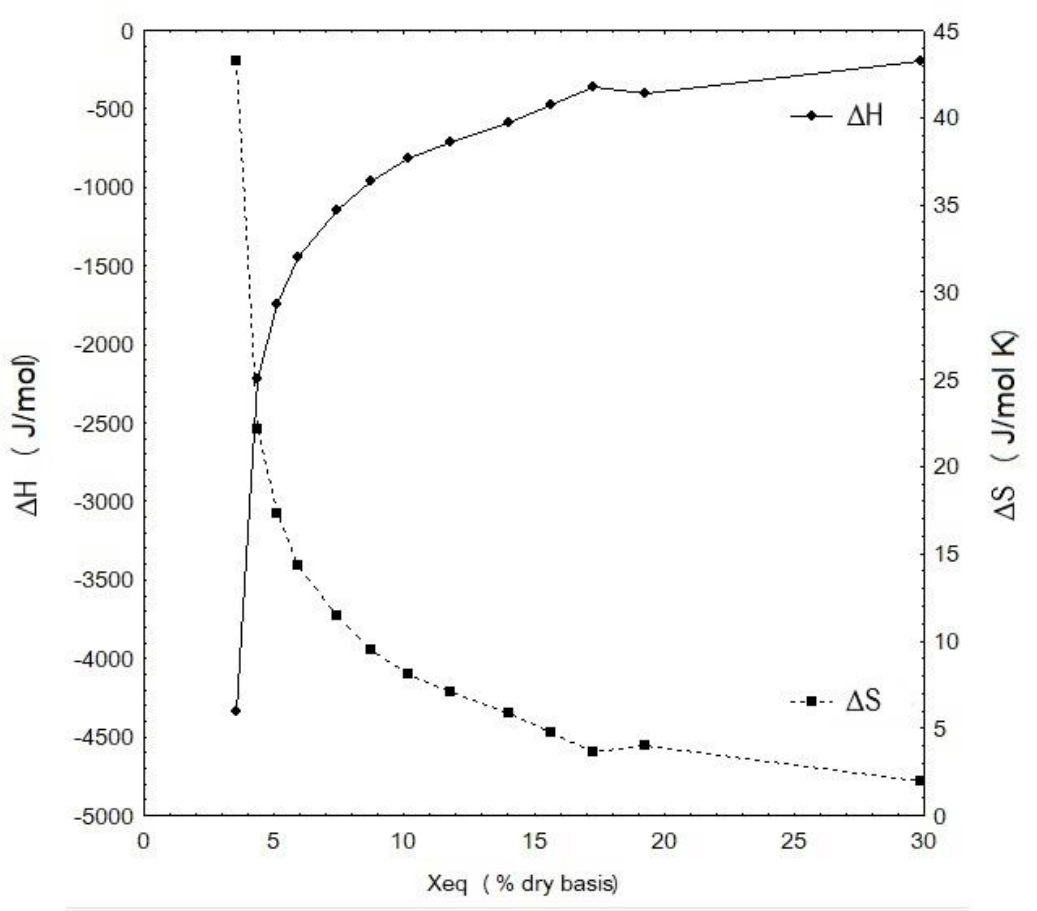

Figure 4. Influence of equilibrium moisture content on enthalpy and entropy change 
Figure 4 shows the differential behavior of enthalpy and entropy associated with the adsorption process, providing information about the reaction in the water / structure system. It is observed that the moisture content directly influences the increase of entropy and the decrease of enthalpy, decreasing the energy necessary to perform a useful work. In theory (Castro-Muñoz, 2018) have shown that increasing water content provides these entropy and enthalpy values due to the structural transformation of solubilization and swelling that allows for greater mobility of adsorbed molecules.

\section{Conclusions}

The present study demonstrated that the adsorption isotherms of juá kernel flour (Ziziphus joazeiro) at temperatures of 293, 303 and $313 \mathrm{~K}$ presented typical type II adsorption behavior, with values of $0<\mathrm{K} \leq 1$ and $\mathrm{C}>2$. In water activities below 0.6 there was a linear increase in equilibrium water content, and above this value this growth was exponential at all temperatures studied. With in the temperature range investigated the GAB model presented the best correlation with the experimental data. The liquid isosteric heat of sorption decreased exponentially with increasing moisture content. Compensation theory demonstrates the dependence between entropy $(\Delta \mathrm{S})$, enthalpy $(\Delta \mathrm{H})$ and equilibrium water content, configuring in a spontaneous and typically enthalpy process. The study provides unprecedented and essential information for the understanding of hygroscopic and thermodynamic parameters, facilitating the subsequent applications of this product, aiming at better storage.

\section{References}

Abebe, W., \& Ronda, F. (2015). Flowability . moisture sorption and thermal properties of tef [Eragrostis tef (Zucc.) Trotter] grain flours. Journal of Cereal Science, 63, 14-20. https://doi.org/10.1016/j.jcs.2015.02.003

Adu, O. B., Ogundeko. T. O., Ogunrinola, O. O., Saibu, G. M., \& Elemo, B. O. (2015). The effect of thermal processing on protein quality and free amino acid profile of Terminalia catappa (Indian Kernel) seed. Journal of Food Science and Technology, 52, 4637-4641. https://doi.org/10.1007/s13197-014-1490-8

Aksil, T., Abbas, M., Trari, M., \& Benamara, S. (2019). Water adsorption on lyophilized Arbutus unedo L. fruit powder : Determination of thermodynamic parameters. Microchemical Journal, 145, 35-41. https://doi.org/10.1016/j.microc.2018.10.012

AOAC. (2000 ). Métodos oficiais de análise da AOAC international (17 ed.). Rockville. MD: AOAC Internacional.

Avhad. M. R., \& Marchetti. J. M. (2016). Mathematical modelling of the drying kinetics of Hass avocado seeds. Industrial Crops \& Products, 91, 76-87. https://doi.org/10.1016/j.indcrop.2016.06.035

Baptestini, F. M., Corrêa, P. C., Vanegas, J. D. B., Leite, R., Botelho, F. M., \& Campos, R. C. (2017). Water sorption kinetics of damaged beans: GAB model. Revista Brasileira de Engenharia Agrícola e Ambiental, 21(8), 550-555.

https://doi.org/10.1590/1807-1929/agriambi.v21n8p550-555 
Blahovec, J. (2004). Sorption isotherms in materials of biological origin mathematical and physical approach. Journal of Food Engineering, 65, 489-495.

https://doi.org/10.1016/j.jfoodeng.2004.02.012

Bligh, E. G., \& Dyer, W. J. (1959). A rapid method of total lipid extraction and purification. Canadian Journal of Biochemistry and Physiology, 37(8), 911-917.

https://doi.org/10.1139/o59-099

Brito, S. M. O., Coutinho, H. D. M., Talvani, A., Coronel, C., Barbosa, A. G. R., Vega. C., ... Menezes, I. R. A. (2015). Analysis of bioactivities and chemical composition of Ziziphus joazeiro Mart . using HPLC - DAD. Food Chemistry, 186, 185-191.

https://doi.org/10.1016/j.foodchem.2014.10.031

Campidelli, M., Carneiro, J. D. D., Souza, E. C., Magalhães, M., Konig, I., Braga, M., ... Boas, E. V. B. V. (2019). Impact of the Drying Process on the Quality and Physicochemical and Mineral Composition of Baru Kernel (Dipteryx Alata Vog.) Journal of Culinary Science \& Technology, 1-13. https://doi.org/10.1080/15428052.2019.1573710

Castro-muñoz, R., \& Nieves-segura, N. (2018). Sorption isotherms and isosteric heat estimation of purple cactus pear (Opuntia stricta) juice embedded in gelatin-maltodextrin matrix. Journal of Food Process Engineering, 41, 1-7. https://doi.org/10.1111/jfpe.12848

Chisté, R. C., Cardoso, J. M., Silva, D. A. da. \& Pena, R. da S. (2015). Hygroscopic behaviour of cassava flour from dry and water groups. Ciência Rural, 45(8), 1515-1521. https://doi.org/10.1590/0103-8478cr20140338

Crapiste, G. H., \& Rotstein, E. (1982). Prediction of Sorptional Equilibrium Data for Starch-Containing Foodstuffs. Journal of Food Science, 47, 1501-1507. https://doi.org/10.1111/j.1365-2621.1982.tb04970.x

Freitas, M. L. F., Polachini, T. C., Souza, A. C. de. \& Telis-Romero, J. (2016). Sorption isotherms and thermodynamic properties of grated Parmesan cheese. International Journal of Food Science \& Technology, 1, 250-259. https://doi.org/10.1111/ijfs.12969

Lisboa, H. M., Araújo, H., Paiva, G., Oriente, S., Pasquali, M., Duarte, M. E., Cavalcanti-Mata, E. R. M. (2019). Determination of characteristic properties of mulatto beans (Phaseolus vulgaris L.) during convective drying. Journal of Agricultural and Food Research, 1, 1-6. https://doi.org/10.1016/j.jafr.2019.100003

Miltal, G. S., \& Usborne, W. R. (1985). Moisture Isotherms for Uncooked Meat Emulsions of Different Composition. Journal of Food Science, 50, 1576-1579.

https://doi.org/10.1111/j.1365-2621.1985.tb10537.x

Nascimento, A., Cavalcanti-Mata, E. R. M., Duarte, M. E. M., Pasquali, M., \& Lisboa, H. M. (2019). Construction of a design space for goat milk powder production using moisture sorption isotherms. Journal of Food Process Engineering, 1-11.

https://doi.org/10.1111/jfpe.13228

Polachini, T. C., Fachin, L., Betiol, L., Lopes-filho, J. F., \& Telis-romero, J. (2016). 


\section{Macrothink}

Thermochimica Acta Water adsorption isotherms and thermodynamic properties of cassava bagasse. Thermochimica Acta, 632, 79-85. https://doi.org/10.1016/j.tca.2016.03.032

Saleh, R., Karim, N. A., Hensel, O., \& Sturm, B. (2018). Mathematical modelling of adsorption isotherms of Malaysian variety of purple $\mathrm{fl}$ esh sweet potato at di $\mathrm{ff}$ erent temperatures. Thermal Science and Engineering Progress, 7, 326-330.

https://doi.org/10.1016/j.tsep.2018.07.007

Silva, J. L da., da Costa, F. B., do Nascimento, A. M., Gadelha, T. M., da Silva, M. S., de Sousa Sátiro, L., \& da Silva, K. G. (2018). Chemical Characteristics and Bioactive Compounds in Juazeiro Fruits Collected in Different Maturation Stages. Journal of Experimental Agriculture International, 1-10. https://doi.org/10.9734/JEAI/2018/44219.

Torres. M. D., \& Seijo. J. (2016). Water sorption behaviour of by-products from the rice industry. Industrial Crops \& Products, 86, 273-278.

https://doi.org/10.1016/j.indcrop.2016.04.014

Yogendrarajah, P., Samapundo, S., Devlieghere, F., Saeger, S. De. \& Meulenaer, B. De. (2015). LWT-Food Science and Technology Moisture sorption isotherms and thermodynamic properties of whole black peppercorns (Piper nigrum L.). LWT - Food Science and Technology, 64(1), 177-188. https://doi.org/10.1016/j.lwt.2015.05.045

\section{Copyright Disclaimer}

Copyright for this article is retained by the author(s), with first publication rights granted to the journal.

This is an open-access article distributed under the terms and conditions of the Creative Commons Attribution license (http://creativecommons.org/licenses/by/4.0/). 